\title{
The Current Context and Future Trends of the Photovoltaic Business Models in Central and Eastern Europe: Case Study-Romania
}

\author{
Adrian Dumitru Tanţău*, Maria Alexandra Nichifor, Horaţiu Regneală \\ Faculty of Business Administration, Bucharest University of Economic Studies, Bucharest, Romania \\ Email: ${ }^{*}$ adrian.tantau@fabiz.ase.ro
}

Received 13 January 2014; revised 13 February 2014; accepted 20 February 2014

Copyright (C) 2014 by authors and Scientific Research Publishing Inc.

This work is licensed under the Creative Commons Attribution International License (CC BY).

http://creativecommons.org/licenses/by/4.0/

(c) (7) Open Access

\begin{abstract}
The evolution of the PV industry has represented one of the main focus points of economic and political debates and research of the last ten years in Europe. However, these discussions have only presented general aspects of the industry development and accomplishments with little information about the companies' actual practices. The present study aims to inquire the PV field in Romania further, by researching the currently implemented and the future business models of firms producing solar energy. Using the Delphi method based on questionnaires and interviews with experts of this field, this paper shows the key elements of business models in the PV field that reflect the companies' practices and future trends and expectations regarding the internal activity of the firm and the environmental changes from the external environment of the company, which influence the directions of the PV domain. The relevance of this study is based on the importance of the applied PV business model elements in order to ensure the survival and expansion of the company in a dynamic field that faces continuous legal, economic and technological changes and challenges. The results of this study have some directions that could be applied in most of the European countries where the PV industry is developing.
\end{abstract}

\section{Keywords}

Business Model; Photovoltaics; Photovoltaic Business Model; Solar Energy

\section{Introduction}

In a very fragile economic environment and a global economy in a deep recession in the last several years, eve-

Corresponding author.

How to cite this paper: Tanţău, A.D., et al. (2014) The Current Context and Future Trends of the Photovoltaic Business Models in Central and Eastern Europe: Case Study-Romania. Smart Grid and Renewable Energy, 5, 43-51. 
rybody is looking for sustainable long-term solutions. Since natural underground resources are limited (coal, oil, natural gas), in recent years, more technology-based solutions "renewable resources (unlimited)" began to develop significantly. In the present paper, we analyze one of these resources, the sun. Photovoltaic industry uses solar energy to produce electricity. This industry has had a tremendous leap in the past 10 years as technology became more accessible and some countries have begun to financially support the industry.

Following the trend given by several European countries to support photovoltaic industry with financial incentives, Romania began to stimulate investment in this area in late 2008 by issuing a law that promotes investment in renewable energies by granting a number of green certificates (different for each type of energy in part). The market began to develop with the publication of the implementing rules of the law that was in late 2011.

In general terms, renewable energy sources have spread exponentially in the last year in Romania, significant quantities of distributed renewable energy are integrated into the grid. In particular, the number of distributed solar-photovoltaic is growing rapidly even with the foresight of green certificates scheme limitation. As distributed PV and other renewable sources can assure an important percent from electricity demand, concerns arise regarding stability and safe operation of the electricity grid. Addressing grid connection and ownership issues is a necessary perquisite for the long term viability of the distributed energy industry, especially PV in both economical and technical areas.

The present study focuses on investigating the current context and new directions for business models in the PV field of Romania by using Delphi method applied with key questions to a selection of experts, investors, engineers acting in the industry. This study will reveal how the Romanian PV market will mirror the economical limitation derived from the reduced support and also grid conditions imposed to PV plants.

\section{The Fundamental Elements of a Business Model}

Business models are widely practiced in companies globally and are considered a key element in order to solve the organization's purposes, the real business practices serving as the most appropriate model for their design and implementation. Thus, although the concept of business model is frequently emphasized due to its importance for a company's success in today's dynamic business environment, the term has not gained yet a generally accepted definition in the scientific research. The literature specifies numerous business elements, that are essential for the creation and implementation of such a model, yet no officially recognized definition has emerged.

According to Osterwalder and Pigneurin [1], a business model describes "the rationale of how an organization creates, delivers and captures value”. Furthermore, Cavalcante, Kesting and Ulhoiin [2], state that a business model should focus on two main objectives of a company, namely: ensuring the stability for the development of a company's activities and the flexibility to enable change implementation within the company.

A business model can also be defined as "the totality of how a company selects its customers, defines and differentiates its offerings, defines the tasks it will perform itself and those it will outsource, configures its resources, goes to market, creates utility for customers and captures profits" and on the whole, the business model must comprise how the entire business system is focused within the company [3].

The development of technology, as well as the globalization process has changed the global competition and the relationship between producers and consumers, by offering customers more transparency to the available products and services and thus increasing their demands and perceived needs [4]. This has led to increased standards of value creation and thus the restructuring of business models for the producers that permanently need to adapt their products and services to the rapidly changing consumer expectations and needs.

As shown in Table 1 one of the most important business model scheme in the scientific literature is represented by the nine building blocks business model, that describes the complexity of a company's orientation towards its customers and activities and all the necessary elements of an organization in order to create and deliver value to the customers. Richter, in [5] also emphasizes a four basic elements business model that incorporates all nine building blocks elements: value proposition, customer interface, infrastructure and revenue model. As to the sensitive elements of a business model, Shafer, Smith and Lindermention in [6] the risk of false assumptions of the core logic or value network, a misunderstood value creation and capturing and the limitations of strategic decisions, that a firm should calculate in advance in order to avoid future failure. A business model represents a complex interconnection of elements, which a company has to consider in order to develop a successful strategy towards delivering customer and stakeholders value. Defining a clear structure of a business model is a challenge for the scientific research, but also for business experts, which permanently strive to dis- 
Table 1. Osterwalder and Pigneur (2010) nine blocks business model.

\begin{tabular}{c}
\hline The 9 building blocks business model of Osterwalder and Pigneur (2010) \\
Customer segments \\
Value proposition \\
Channels \\
Customer relationships \\
Revenue streams \\
Key resources \\
Key activities \\
Key partnerships \\
Cost structures
\end{tabular}

cover new elements, that could establish the key elements of suitable strategy alternatives in their activity field. Johnson, Christensen and Kagermann in [7] have proposed another structure of a company's business model that concentrates the previous business model elements in four main structures: customer value proposition, profit formula, key resources and key processes, as shown in Figure 1.

All of the above mentioned theories on business models practically agree on the same fundamental elements a business model should include: for instance, value proposition, that represents the value creation for customers through the products and services the company offers to satisfy the customer needs; the importance of the company's orientation towards its clients from customer segmentation to delivery and creating and maintaining customer relationship for each segment. Furthermore, the key resources are the resources needed in order to create and deliver value for customers, while other important factors are the people, products, the technology, channels, information, partnerships and brand, as seen in Table 1 and Figure 1.

Another definition mentions apart from the common four element business model: the design of the supply chain and the design of the transactions of a firm in creating value as other key elements of the model design [8].

Common to all the above mentioned definitions of a business model is practically the way a company focuses and organizes its activities, architecture and structure towards capturing value by means of all its efforts within the company and in the market.

\section{Photovoltaics Business Models}

The photovoltaic industry represents the third most important source of renewable energy, after the hydro-and wind energy and a most promising direct source of electricity for consumers in the near future [9]. The production of solar energy was regarded not long ago as a field, that required a professional working environment in order to be obtained, but today photovoltaic systems are projected based on a new vision: the local production and consumption of solar energy and the involvement of customers or third-parties in the field.

In the photovoltaic field, the same elements of the theoretical business models can be applied with the introduction of two new key partners and their specific activities and resources: suppliers of PV systems and local installation companies besides the traditional project developers, research institutions and government.

Furthermore, the existing business models in the PV field, that are already implemented by companies activating in this domain, can be divided in two particular types: the utility-side PV business model and the customer-side PV business model, each of them offering specific rights and obligations towards the utility or the customers.

The PV business models can be divided into three specific models:

1) The customer owned PV business model (illustrated in Figure 2), where the customer holds responsibility forall derived costs of the business, but also the benefit of all revenues [10].

This type of business model is the most wide spread model in the world at the present moment. The costs reflecting the services of a distributor are beard by the direct customer or indirectly in case of an "on grid" system. Even if the role of the distributor is not active, they must get involved in the maintenance of the network at func- 


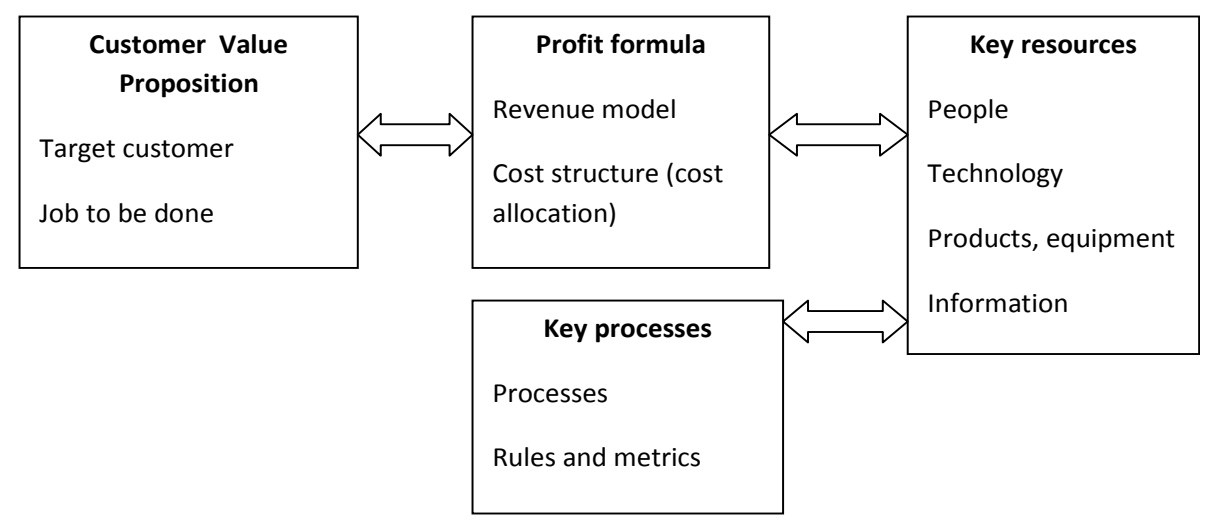

Figure 1. The elements of a successful business model according to Johnson et al. (2013).

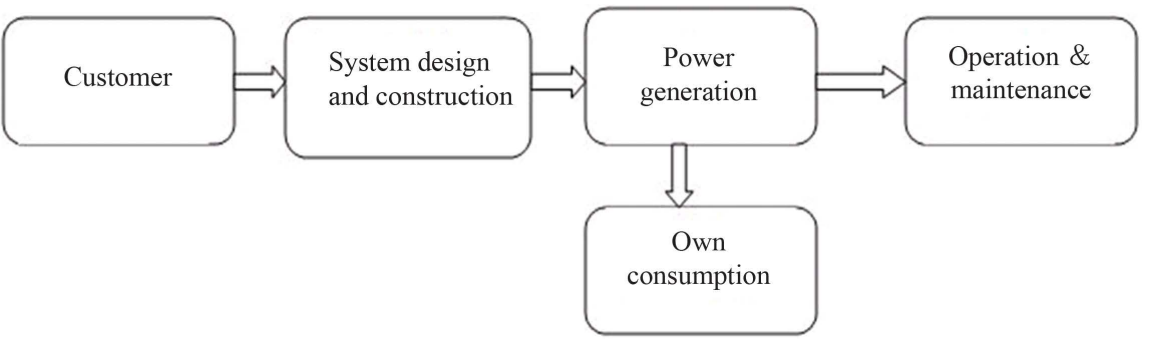

Figure 2. The customer owned PV business model scheme.

tional parameters and its modernization if that is the case.

The main advantage for the clients that hold their own photovoltaic systems is that they benefit directly $100 \%$ of the produced electrical and simultaneously bear all the costs and financial and operational risks in time. At the same time the client benefits of the effectual supporting scheme facilities at that moment.

There is also a delay between the moment when the client completes the project and the moment they recover their investment through energy and green certificates selling. The type of system called "off grid" will reduce the electrical energy billing costs of the client and serves as a cover against the rising electrical energy price, but the exact calculation of economical benefits on long term is a difficult task. For a company, that owns a photovoltaic park, the business risk is low on a long term after the installation process is completed. Some installers can offer long-term financing, the monitoring of the park and maintenance contracts. In its most simple form the system is installed by the solar company and paid by the client with few additional obligations.

2) The third party owned PV business model (shown in Figure 3), where a photovoltaic system owned by a company, that develops and operates photovoltaic systems can be rented as a fix, monthly payment or based on a price per delivered kWh in exchange for the installing of the PV system on the client's property roof. The end customer may gain substantial savings of the energy bill on a long term even if the PV system will not fully cover its energy necessities. The main advantage of this type of customers that rent their house tops are represented by initial low costs or even lack of costs.

The client's benefits are correlated with some risks that can be described through economical and technological compromises.

The benefits gained from the energy savings will be shared between the client and the solar company according to the concluded contract. If the electrical energy price will increase, the client's earnings will increase as well (for the part that is annually compensated by solar). The PV company bears the responsibility of multiple issues, that the customer must not face, such as the system installation and start, its operation, maintenance and performance.

However, the clients have a long-term obligation: the monthly payment of the PV company (similar to the payment system towards the local utility company).

3) The utility owned business model (described in Figure 4) refers to the power plants that directly own and control the system, while establishing only business-to-business power purchasing agreements (PPAs) without 


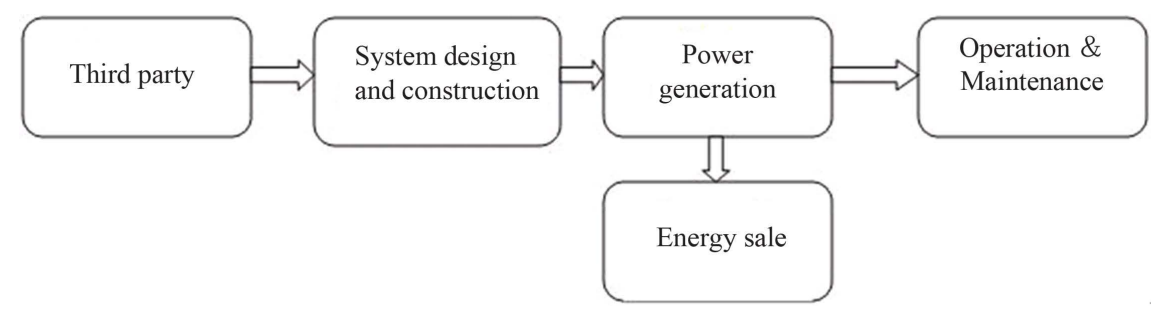

Figure 3. Third party owned PV business model scheme.

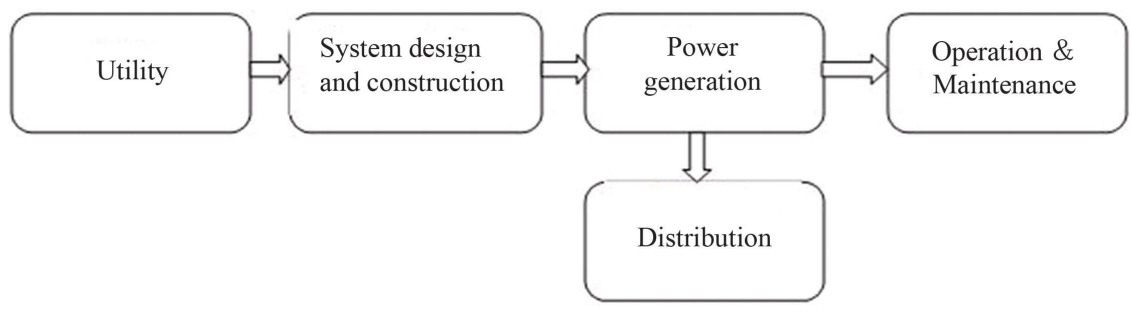

Figure 4. Utility owned PV business model scheme.

involving end-customers [11]. The utility rents or buys the land, where the PV park will be installed, outsources the building of the park in most cases, but operates the PV system similarly to a company's asset on a long term. Utility-owned PV systems exist at a small-scale in the present context, but most likely their number will increase in the near future.

Thus, the business models in the photovoltaic field are developing new ways of value creation for the company and for the third party or customer, as well as for an increased efficiency for assets and activities orientation.

As to which of the models would be most efficient for a company, this depends on the context of the external and internal company's factors in each situation. For instance, the utility controlled, but third party or customer owned business model is considered appropriate where there is a high penetration of PV systems, that may cause grid malfunctions or when the demand response is aggressive, while the third party or customer controlled and owned PV business model may be used if there is no external influence, as seen in [11].

The PV business models are permanently adding new types of activities, power purchasing agreements and resources that are forming the fundamental elements of future scientific research and PV market development. For some issues, what is good for customers can also be good for the solar industry and utilities. In other issues, there are fundamental conflicts of interest that require compromise or resolution. Some of these challenges flow from the ownership structure itself, while others depend on the metering configuration underlying the ownership.

\section{Methodology}

The objective of the present study is to investigate the current context and new directions for business models in the photovoltaic (PV) field in Romania. For this purpose, the Delphi method has been used to ensure a practical perspective of the researched field, by consequently following the classical phases of this method: selection and definition of the research field and objective, the preparation of the questionnaires, the selection of experts, that would be interviewed, the first round of online, individual interviews with the experts, the analysis of results, results reporting to the experts, the second round of interviews, the analysis of the results and the informing of the experts and the elaboration of the Delphi report [12]. This method was implemented for questioning the experts of companies in order to gain an insight into the business models implemented by their companies and the future expected trends in the field.

We conducted interviews with 25 experts, members of companies in the photovoltaic field in Romania. We have formulated questions referring to the nine building blocks model elements for the interviewed experts with the intention of gaining an insight into the current business models implemented by firms in the PV field and the potential development of these models in Romania. The first part of the interviews inquired six of the nine building blocks and the specific PV business models currently used by the experts' companies, while the second 
part was projected to reevaluate these indicators and based on the reports from the first round to formulate potential future trends of the business models in the PV business.

All of the interviewed experts were active in companies operating in the PV field: $78 \%$ of them were focused only on the production of solar energy, while $22 \%$ were producing two or more types of renewable energy besides solar energy, respectively wind energy, biomass, hydro energy, bio-fuel, geothermal energy, generic technologies and other. A part of our respondents began their investments due to the renewable energy conjuncture starting with 2008 until present time, while the majority of them represent well-established companies in the energy field. The profile of the analyzed companies could be classified as follows: investors (22\%), project developers (22\%), EPC contractors (28\%), consulting company in the field (24\%) and other (4\%). Of the 25 respondent companies $64 \%$ had a diversified profile, activating simultaneously in two or more of the above mentioned qualities. The majority of the researched firms (60\%) are companies with maximum 50 employees, while $32 \%$ have 50 - 100 employees and only $8 \%$ have more than 500 employees.

The research was extended over a time span of approximately five months, between 1st of May until the 30th September 2013.

\section{Findings and Analysis}

In order to explore the fundamental elements of a business model in a PV field, we based our study on the inquired theoretical background of the mentioned authors, who have illustrated a main scheme of what a successful business model could contain.

The hypothesis of our inquiry were:

H1: The most frequently used business models by PV companies in the current context in Romania are "Photovoltaic plant that is the property of and operated by their own company with energy sales to a trading entity (different than the grid operator)" and "Photovoltaic plant that is the property of and operated by their own company with energy sales to the local grid operator (the one which the connection contract has been signed with)".

Q2: In the next five years the future trend of PV business models in Romania will be represented by "Photovoltaic plant that is the property of and operated by their own company with energy sales to a trading entity".

The first part of the interviews inquired six of the nine building blocks of Osterwalder and Pigneur in [1], while the second part was projected to reevaluate these indicators and based on the reports from the first round to formulate potential future trends of the business model in the PV business.

The most important finding of our study referred to the current business models applied in the PV companies: the majority of our respondents (48\%) stated that their company currently uses the "Photovoltaic plant that is the property of and operated by their own company with energy sales to a trading entity (different than the grid operator)", $17 \%$ prefer the "Photovoltaic plant that is the property of and operated by their own company with energy sales to the local grid operator (the one which the connection contract has been signed with)", while $10 \%$ apply the business model "Photovoltaic plant that is the property of and operated by their own company with energy sales to a third-party entity". Only 7\% of the interviewed experts have implemented the "Photovoltaic plant that is the property of and operated by a local grid operator". The rest $17 \%$ apply other business models in their company, as shown in Figure 5. The preference for the first type of business model that was applied by almost half of our respondents could be explained by the flexibility of negotiation and advantages in contracting trading companies that often offer more advantages in comparison to the large local distributors. The described business models coincide in case of the PV field with customer segments of Osterwalder model.

The above results from the first part of the interviews are more interesting as the future business models with the highest development potential in Romania described in the second part of the questioning coincided with the first two most applied business models in the firms "Photovoltaic plant that is the property of and operated by their own company with energy sales to a trading entity (different than the grid operator)" (36\%) and "Photovoltaic plant that is the property of and operated by own company with energy sales to the local grid operator (the one which the connection contract has been signed with)" (16\%). The third position with an equal percentage of $16 \%$ was "Photovoltaic plant that is the property of and operated by their own company with energy usage for internal consumption", which was not chosen by any of the respondents in the first round of interviews. This could be explained through the fact that for this kind of PV plant no government subsidies are offered and thus, it is not convenient to invest in such a business that implies high production costs for the PV energy. 

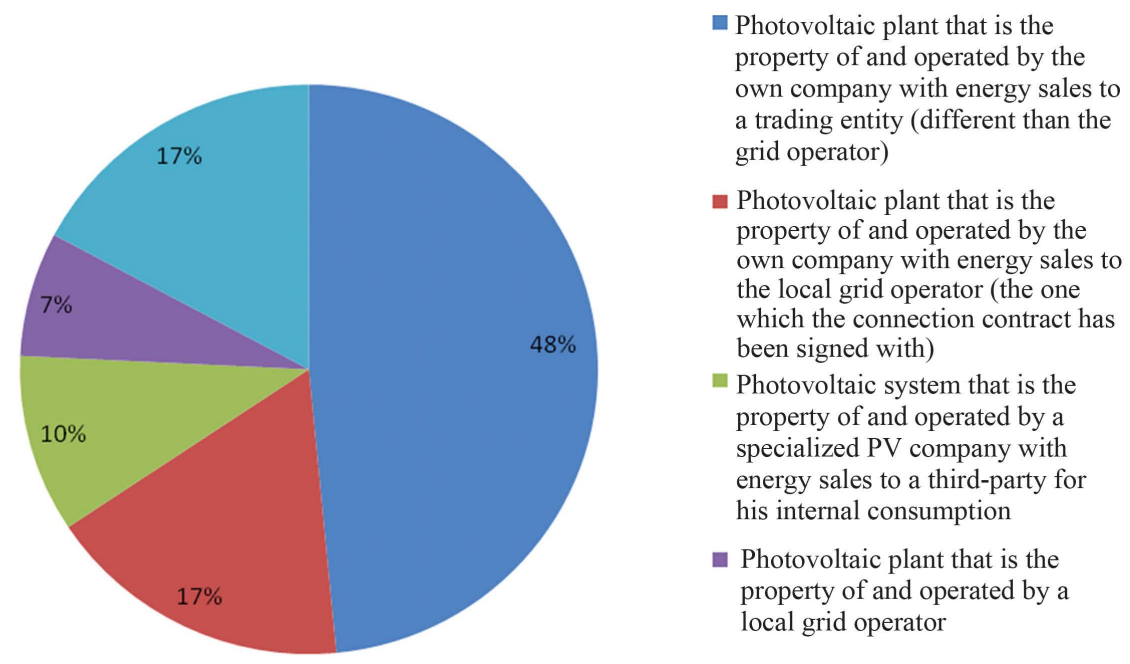

Figure 5. Currently implemented business models in the photovoltaic field in Romania.

The last two business models gained each an equal share of $12 \%$ of the votes, while $8 \%$ stated other types of business models as being the potential models with a high development in the future in Romania, such as "Photovoltaic system that is the property of and operated by a specialized PV company with energy sales to a thirdparty for his internal consumption”. The results regarding the predictions in the PV field in Romania differ slightly from the ones regarding the current situation because of their connection to multiple internal factors. On the one hand, the green certificates legislation for each produced and delivered MWh in the network by a PV system has changed since July 1st 2013 and is going to face new modifications in the near future, while on the other hand, the Romanian market started to mature through the diversification and development of other business segments in the field. Based on the history of other European countries, that have had experiences in this field, the next natural phase would be the support of small systems that produce a maximum of 1 MWp (through the introduction of a "feed-in tariff", which would facilitate the development of such systems on the buildings' rooftops). Even without any government subventions the industry can expand based on solid arguments, such as the energetic independence of the consumer, protection against massive energy price fluctuations, as well as the personal contribution towards environmental protection.

Another important part of the inquiry was the perception about the legal framework in Romania and its influence on the PV field (Figure 6). The majority of experts (65\%) see the actual context as an opportunity context, while $35 \%$ see the actual context as insecure and lacking opportunities. However, $81 \%$ of the experts mentioned a certain degree of insecurity of the legal context in Romania.

The revenue streams were analyzed through the preferred forms of investment in the photovoltaic field, the first choices being: construction (29\%), land acquisition, design, construction and operation (26\%) and land acquisition and design ("ready to build"-stage) (17\%) as seen in Figure 7.

In the medium term future (1 - 5 years) $68 \%$ of the respondents do not intend to sell their assets in the PV field, while only $16 \%$ intend to sell a part of them and $12 \%$ stated they would sell all of their assets. The rest mentioned other intentions. As one can see, only few of the interviewed experts are investors by conjuncture (12\%), while the others have had a vast experience in the field or long-term intentions regarding the development of this type of business in Romania, which offers a note of continuity of the domain ever since its starting phase on a national level.

Furthermore $72 \%$ of the experts stated they would continue to invest in the photovoltaic field, while only $28 \%$ declared the opposite. Other fields of investment, that present an interest to the latter, who do not intend to invest in solar energy are: other types of energy (36\%) and 16\% agriculture. The other respondents mentioned services or technical products and applications as their future fields of investment. Referring to the elements that differentiate the products and services of a company from its market competitors, $72 \%$ of the specialists consider that their products/services characteristics considered better comparing to the ones of the competition represent the competitive advantage of their firm, while only $21 \%$ believe that price is the key advantage. Other elements of distinction were chosen by only $7 \%$ of the respondents. 


\section{Perceived current context of the PV field in Romania}
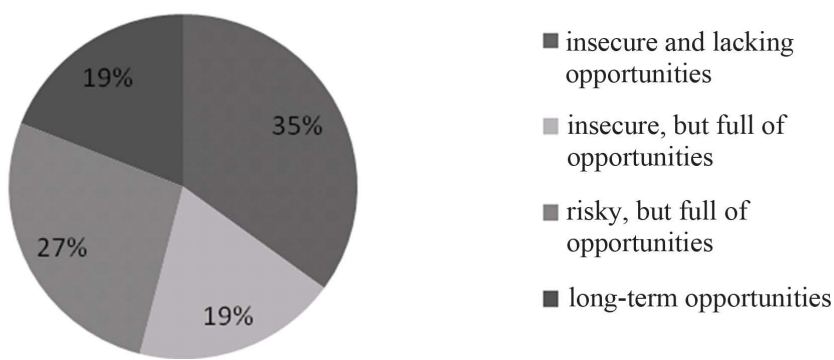

Figure 6. Perceived current PV situation in Romania regarding the legal framework.

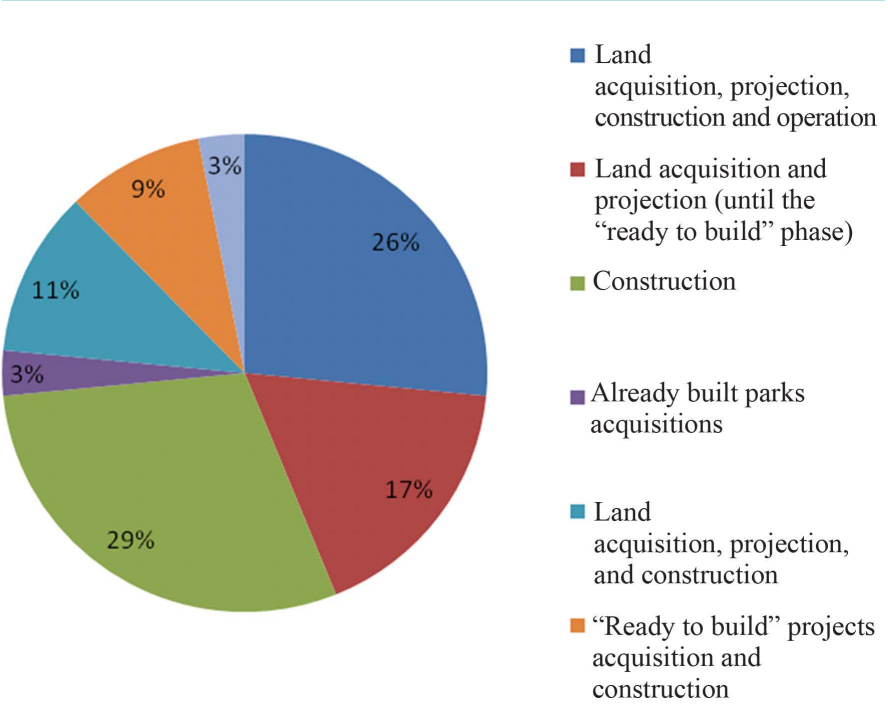

Figure 7. Forms of investment in the PV field.

Strategic partnerships also played an important part: besides the classical forms of partnerships, the PV field also offers the partnership between the PV company and the general contractor or a contractor/subcontractor. All questioned respondents stated they had cooperated in classical forms of strategic partnerships (strategic alliances, joint venture, fusions, acquisitions), while $64 \%$ felt the need for a general contractor for the construction and operation of PV systems, even if the company was part of the project.

\section{Conclusions}

As a conclusion, the first hypothesis regarding the most frequently implemented business models used within PV companies in Romania was confirmed by the two described models, respectively "photovoltaic plants that are the property of and operated by their own company with energy sales to a trading entity (different than the grid operator)" and "the photovoltaic plant that is property of and operated by their own company with energy sales to the local grid operator". The expectations for the next five years referring to the most implemented PV business model in Romania have also been stated by the interviewed experts, who have emphasized the model of "photovoltaic plants that are the property of and operated by their own company with energy sales to a trading entity (different than the grid operator)" as the most preferred form of business model due to the negotiation flexibility of trading companies. Thus, the second hypothesis of our study was also confirmed by the interviewed experts. The photovoltaic systems that are the property of and operated by a specialized PV company with energy sales to a third-party for his internal consumption that are assumed in practice as business models 
with a high future potential in Romania, seem to have gained a minor share of the votes, but still present an interest to the PV companies that have already expanded their activity in this type of business model.

The current and future trends of PV business models that can be observed throughout the study can be explained perhaps not only by internal objectives of financial gain or PV parks expansion, but also by the external regulations and transformations that have occurred in the last five years. In those years since the PV supporting scheme (2008) was adopted, the market has encountered major transformations. The first two years (2009 and 2010) while there were no norms for the scheme applications, only one MWp was constructed, the following two years have brought the norms of application of the PV supporting scheme and thus the construction of PV parks accumulating a few tens of MWp. The year 2013 represented a boom of the PV industry, meaning the implementation of a few hundred MWp. The law modification on the 1st July 2013 all investors of this field have accelerated their investment processes until the end of the year 2013, when it is expected that the law will suffer new modifications.

The PV market has numerous factors, such as specialized companies in the energetic field that have entered this niche, as well as opportunity investors that intend to speculate this favorable period on the market. As these phases have been fulfilled throughout the last five years, the Romanian PV market has matured, turning from the uncertainty and lack of security at the beginning (in the years 2008-2011) towards optimism and boom in 2013. The expectations for 2014 include a lagging of the market through subventions reductions or cuts. At the same time, the market of the large-scale systems (greater than $1 \mathrm{MWp}$ ) that benefits or lacks financial facilities, will gradually be replaced by the small-scale systems, installed on the rooftops. On a mediumor long term the PV components technology will expand and as a result this type of technology will be more and more accessible for companies from the financial perspective. Off-grid systems are expected to develop gradually due to this low cost of technology (including batteries).

Romania is currently following the usual trend of the industry that has a history of ten years on a European level and that has initially started in economically developed countries and has been later adopted by developing countries.

\section{References}

[1] Osterwalder, A. and Pigneur, Y. (2010) Business Model Generation. John Wiley \& Sons, Hoboken.

[2] Cavalcante, S., Kesting, P. and Ulhoi, J. (2011) Business Model Dynamics and Innovation: (Re)Establishing the Missing Linkages. Management Decision, 49, 1327-1342. http://dx.doi.org/10.1108/00251741111163142

[3] Morris, M., Schindenhutte, M. and Allen, J. (2003) The Entrepreneur’s Business Model: Toward a Unified Perspective. Journal of Business Research, 58, 726-735. http://dx.doi.org/10.1016/j.jbusres.2003.11.001

[4] Teece, D. (2010) Business Models, Business Strategy and Innovation. Long Range Planning, 43, 172-194. http://dx.doi.org/10.1016/j.lrp.2009.07.003

[5] Richter, M. (2011) Mastering the Energy Transition. A Review on Utilities’ Business Models for Renewable Energies. http://www2.leuphana.de/umanagement/csm/content/nama/downloads/download_publikationen/Richter_Mastering_the _Energy_Transition.pdf

[6] Shafer, S.M., Smith, H.J. and Linder, J.C. (2005) The Power of Business Models. Business Horizons, 48, $199-207$. http://dx.doi.org/10.1016/j.bushor.2004.10.014

[7] Johnson, M.W., Christensen, M.C. and Kagermann, H. (2008) Reinventing Your Business Model. http://www.ondernemenzondergrenzen.nl/uploaded_files/6_reinventing_your_business_model.pdf

[8] Weil, P., Malone, T.W., Herman, G. and Woerner, S. (2005) Do Some Business Models Perform Better than Others? A Study of the 1000 Largest US Firms. http://ccs.mit.edu/papers/pdf/wp226.pdf

[9] Masson, G., Latour, M. and Biancardi, D. (2012) Global Market Outlook for Photovoltaics until 2016. http://www.epia.org/uploads/tx_epiapublications/Global-Market-Outlook-2016.pdf

[10] Graham, S., Katofsky, R., Frantzis, L., Sawyer, H. and Margolis, R. (2008) Future of Grid-Tied PV Business Models. SOLAR 2008-American Solar Energy Society (ASES), San Diego, 3-8 May 2008, 1-8. http://www.nrel.gov/docs/fy08osti/42985.pdf

[11] Frantzis, L., Graham, S., Katofsky, R. and Sawyer, H. (2009) Photovoltaic Business Models. http://www.nrel.gov/docs/fy08osti/42304.pdf.

[12] Häder, M. (2009) Delphi-Befragungen. Ein Arbeitsbuch, VS Verlag für Sozialwissenschaften, Wiesbaden. http://dx.doi.org/10.1007/978-3-531-91926-3 